\title{
Effect of tannery wastes and biochar on soil chemical and physicochemical properties and growth traits of radish
}

\author{
Fereshteh Nabavinia, Hojat Emami*, Alireza Astaraee, and Amir Lakzian \\ Department of Soil Science, Ferdowsi University of Mashhad, Mashhad-Iran
}

Received December 14, 2014; accepted June 1, 2015

\begin{abstract}
A b s t r a c t. Tannery wastes can be used in soil as organic manure. The aim of this research was to study the effects of tannery wastes (before a chromium addition step) and biochar on soil chemical and physicochemical properties and radish yield. Treatments included three levels of tannery waste $(0,2.5$, and $5 \%)$ and two levels of biochar ( 0 and $\left.2.5 \mathrm{t} \mathrm{ha}^{-1}\right)$ in a completely randomized design (factorial) with three replications. The treated pots were kept under field capacity condition for three months; thereafter, five radish seeds were sown at $1 \mathrm{~cm}$ depth in soil of each pot. The results showed that tannery wastes and biochar treatments resulted in an increase in soil nitrogen and phosphorus contents and their concentrations in radish root and above ground biomass, but electrical conductivity of soil was decreased and had no effect on soil potassium content. The tannery waste treatment increased soil $\mathrm{pH}$ after plant harvest. It also significantly increased radish fresh and dry matter weight, but the biochar treatment yielded a slight increase. It is concluded that application of tannery wastes and biochar may be useful due to their high nutrient contents in soils lacking organic carbon under arid and semi-arid regions, thereby improving growth and increasing plant yield.

$\mathrm{K}$ e y w o r d s: nutrients, plant growth, organic matter
\end{abstract}

\section{INTRODUCTION}

Tanning industry generates large quantities of solid wastes during the leather manufacturing process and subsequently during effluent treatment. During this process, different wastes produced include meat separated from skin, fat tissue, hair, sludge, and chromium (Meehan et al., 2001). The quantity of wastes from tanneries depends on the type of the leather manufacturing process, skin resource, and techniques used. At the end of the leather manufacturing process, around $20 \%$ of the weight of raw skin is changed to leather (Basegio et al., 2009). The types of tannery solid wastes are generally divided into three groups as: - skin hair which is separated by ferrous sulphate, these wastes are in the form of mass and wet material,

*Corresponding author e-mail: hemami@um.ac.ir
- oily sludge: fat tissue which is separated from skin and to some extent without pollution,

- chromium sludge: includes partially digested tissues and chromium, which is heavy with green and dark blue cover, which are among the most risky wastes (Meehan et al., 2001).

Sludge produced in the last two steps is blended and brought to landfills. Because of high chromium content, it cannot be used in agriculture (Dudka and Miller, 1999). Francisco et al. (2011) reported that nitrogen, phosphorus, and potassium contents and also plant growth, especially vegetative parts, were increased by application of tannery wastes to soil. Sommers (1977) reported that the potassium concentration in tannery waste is $0.02-2.6 \%$, which is enough for plant uptake. Use of $25,50,75$, and $100 \%$ tannery wastes increased germination of cabbage and Swiss chard and chard stem growth (Francisco et al., 2011). Several studies showed that solid and liquid tannery wastes may balance soil acidity. The increase in soil $\mathrm{pH}$ may be due to the use of lime for hair removal in the tannery process (Konrad and Castilhos, 2002).

Biochar is charcoal produced from plant biomass and agricultural wastes during the pyrolysis process. This process is a slow burning of organic material in the deficiency of oxygen or even without it. The main difference between biochar and charcoal is mainly the end product. Use of biochar is common in acid soils of tropical regions (Kimetu et al., 2008). In addition, some reports provide new information in the use of biochar in temperate regions (Laird, 2009). Nigussie et al. (2012) reported that nutrient uptake by plants was increased in soils treated with biochar, due to an increase in microbial biomass and activity. Biochar has greater sorption ability than natural soil organic matter due to its greater surface area, more negative surface 
charge, and charge density. Thus, the addition of biochar to soil may benefit the environment by preventing nutrients loss and thereby protecting water resources. Furthermore, soils containing biochar have a strong affinity for organic contaminants (Yu et al., 2009). Most experiments were conducted in tropics using biochar produced in local earthen kilns and applied to soils with low organic matter content (Laird, 2008). The varying effects on crop yield appear to depend on such factors as biochar quality, biochar amounts added, soil type, and crop tested. Mixing biochar with other soil amendments like manure fertilizer, compost, or lime before tillage operation can increase performance with reduction in the number of needed tillage operation. Uptake of nutrients by biochar can prevent their loss through leaching (Major, 2009).

The role of tannery wastes and biochar in improvement of chemical properties and soil fertility was studied in a variety of research, but the combined effects of a mixture of tannery wastes and biochar have not been considered yet. Therefore, the present work was conducted with the aim of considering the effects of biochar, tannery wastes (the first part included hair and skin wastes), and their mixture on soil chemical and physicochemical properties and radish plant yield and chemical composition.

\section{MATERIALS AND METHODS}

This work was conducted in a completely randomized design (factorial) with three replications at three levels of tannery waste $(0,2.5,5 \%)$ and two levels of biochar $(0,2.5$ $\left.\mathrm{t} \mathrm{ha}^{-1}\right)$ to determine their effect on soil chemical properties and radish plant. Soil sampling was done in an agricultural field in the Ferdowsi University of Mashahad. The treated and untreated (control) soils were kept under field capacity conditions for three months in a greenhouse. Five radish seeds were sown in each pot (5 $\mathrm{kg}$ weigth) and irrigation was done with tap water during plant growth. Plants in each pot were harvested after 150 days. Afterwards, the disturbed soil samples were collected for measuring chemical properties. Some chemical properties of the soil samples were measured after air drying and passing the disturbed soil samples through a 2-mm sieve. Total nitrogen was measured with the Kejeldal method (Page et al., 1982). In this method, organic $\mathrm{N}$ is converted into $\mathrm{NH}_{4}$ through digestion with $\mathrm{H}_{2} \mathrm{SO}_{4}$. $\mathrm{NH}_{4}$ is separated after distillation by vapour carrying, resulting from the addition of a concentrated $\mathrm{NaOH}$ solution to the digestion extract. The ammonia produced is carried by water vapour and collected in a boric acid solution containing the detection substance. The borate is retro titrated with $\mathrm{H}_{2} \mathrm{SO}_{4}$ standardized solution. The amount of acid used in the titration is proportional

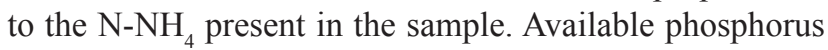
was measured with the Olsen method - a WAP spectrometer (Richards, 1954). The method is based on the use of a $0.5 \mathrm{M}$ sodium bicarbonate $\left(\mathrm{NaHCO}_{3}\right)$ solution at a $\mathrm{pH}$ of 8.5 to extract $P$ from calcareous, alkaline, and neutral soils. The available potassium was also determined in a neutral normal ammonium acetate $\left(1 \mathrm{~N} \mathrm{CH}_{3} \mathrm{COONH}_{4}\right)$ extract of soil with a flame photometer JENWAY (Page et al., 1982). In addition, electrical conductivity of soil was measured with an electrical conductivity meter JENWAY 4310 and $\mathrm{pH}$ in a 1:5 soil-to-water ratio with a $\mathrm{pH}$ meter Ohmmeter 632 (Richards, 1954). Plant parameters like total above ground biomass and root fresh and dry weight, root length and diameter were measured after plant harvest. Statistical analysis of the data was performed using JUMP4 software and means were compared with Tukey's test at a 5\% significance level.

\section{RESULTS AND DISCUSSION}

The results showed that 2.5 and $5 \%$ addition of tannery wastes increased total soil nitrogen (TN) by 47 and $28 \%$, respectively, compared to the control (Table 1), due to the high content of nitrogen in tannery wastes (Table 2); hence, their addition to soil resulted in a significant increase $(\mathrm{p}<0.05)$ in soil nitrogen. According to the Agriculture and Resource Management Council of Australia and New Zealand (ARMCANZ), skin hair which is separated in the first step of leather tanning, has a lot of nitrogen and the chromium

T a b l e 1. Effect of tannery wastes and Biochar on soil chemical properties

\begin{tabular}{lccccc}
\hline \multirow{2}{*}{ Treatment } & $\begin{array}{c}\mathrm{TN} \\
(\%)\end{array}$ & $\mathrm{P}_{\text {avil }}$ & $\mathrm{K}_{\text {avil. }}$ & $\begin{array}{c}\mathrm{EC} \\
\left.(\mathrm{dS} \mathrm{m})^{-1}\right)\end{array}$ & $\mathrm{pH}$ \\
\cline { 3 - 4 } & $0.058 \mathrm{c}$ & $17 \mathrm{c}$ & $4900 \mathrm{a}$ & $0.77 \mathrm{c}$ & $8.56 \mathrm{~b}$ \\
$\mathrm{TW}_{0}$ & $0.075 \mathrm{~b}$ & $27 \mathrm{~b}$ & $4910 \mathrm{a}$ & $0.85 \mathrm{~b}$ & $8.59 \mathrm{~b}$ \\
$\mathrm{TW}_{2.5}$ & $0.086 \mathrm{a}$ & $29 \mathrm{a}$ & $4919 \mathrm{a}$ & $1.00 \mathrm{a}$ & $8.63 \mathrm{a}$ \\
$\mathrm{TW}_{5}$ & $0.063 \mathrm{~b}$ & $22 \mathrm{~b}$ & $4912 \mathrm{a}$ & $0.83 \mathrm{a}$ & $8.57 \mathrm{a}$ \\
$\mathrm{B}_{0}$ & $0.084 \mathrm{a}$ & $27 \mathrm{a}$ & $4940 \mathrm{a}$ & $0.92 \mathrm{~b}$ & $8.58 \mathrm{a}$ \\
$\mathrm{B}_{2.5}$ & & & & & \\
\hline
\end{tabular}

Same letters not significant at $\mathrm{p}<0.05$. $\mathrm{TW}_{0}-0 \%, \mathrm{TW}_{2.5}-2.5 \%, \mathrm{TW}_{5}-5 \%$ of tannery waste; $\mathrm{B}_{0}-0$, and $\mathrm{B}_{2.5}-2.5 \mathrm{t}$ ha ${ }^{-1}$ of Biochar. 
T a b l e 2. Some physical- chemical properties of soil, tannery wastes, and biochar before the start of the experiment

\begin{tabular}{lccc}
\hline Properties & Soil & Tannery wastes & Biochar \\
\hline Texture & Loamy sand & - & - \\
$\mathrm{pH}(1: 5)$ & 8.5 & 9.6 & 9 \\
EC $(1: 5)\left(\mathrm{dS} \mathrm{m}^{-1}\right)$ & 0.75 & 17.0 & 1.71 \\
Total N (\%) & 0.059 & $1560^{* *}$ & 0.5 \\
Phosphorus $\left(\mathrm{mg} \mathrm{kg}^{-1}\right)$ & $15^{*}$ & $390^{* *}$ & $500^{* *}$ \\
Potassium $\left(\mathrm{mg} \mathrm{kg}^{-1}\right)$ & $301^{*}$ & $8200^{* *}$ \\
\hline
\end{tabular}

*Available phosphorus and potassium, ${ }^{* *}$ total phosphorus and potassium.

content is below standard values, and fortunately it has high potential for reuse as a nitrogen source (Meehan et al., 2001). Oliveira et al. (2008) demonstrated that tannery wastes are rich in nitrogen and can be used as a good fertilizer alternative. Addition of biochar to soil resulted in a $33 \%$ increase in total soil nitrogen that differed significantly $(\mathrm{p}<0.05)$ from the control (Table 2). The interaction effect of biochar and tannery wastes on soil nitrogen showed an increase in soil nitrogen (Fig. 1a). The $\mathrm{TW}_{5} \mathrm{~B}_{25}$ treatment yielded a higher increase in soil $\mathrm{N}$ by $98 \%$ compared to the control. Both biochar levels with addition of tannery wastes increased soil nitrogen significantly $(p<0.05)$. It seems that biochar with the organic fertilizer had a more pronounced effect on the increase in soil nitrogen. The $\mathrm{TW}_{2.5} \mathrm{~B}_{2.5}, \mathrm{TW}_{5} \mathrm{~B}_{0}$, $\mathrm{TW}_{0} \mathrm{~B}_{2.5}$, and $\mathrm{TW}{ }_{2.5} \mathrm{~B}_{0}$ treatments increased soil nitrogen by $74,50,36$, and $30 \%$ respectively, compared to the control. Similarly, biochar application at all the levels of tannery wastes significantly increased soil nitrogen $(\mathrm{p}<0.05)$. Some researchers showed that biochar application can increase the uptake and efficiency of nitrogen fertilizers in soil as a result of lowering nitrogen leaching and also by affecting the soil nitrogen cycle (Yao et al., 2012). The positive results of biochar have been described more fully for acidic soils and tropical areas; but there are not many studies done in respect to the biochar effect in alkaline soil and application thereof together with tannery wastes.

The results of the addition of tannery wastes to soil showed that soil phosphorus increased with the $\mathrm{TW}_{2.5}$ and $\mathrm{TW}_{5}$ treatments by 59 and $71 \%$, respectively, compared to the control (Table 2). Francisco et al. (2011) reported an increase in soil phosphorous due to addition of tannery wastes. Biochar contains phosphorus (Table 1) and its addition to soil increased soil P by $22 \%$, compared to the control (Table 2). Nigussie et al. (2012) reported a soil phosphorus increase by biochar addition of 5 and $10 \mathrm{tha}^{-1}$. The interaction effect of biochar and tannery wastes resulted in a significant increase in soil P (Fig. 1b). Biochar can increase nutrient pools in soil due to its highly exchangeable sites and addition thereof along with tannery wastes can increase soil essential nutrient contents. At both biochar levels, with the increasing amounts of tannery wastes, soil $\mathrm{P}$ significantly $(p<0.05)$ increased (Fig. 1b). The highest levels of biochar and tannery wastes $\left(\mathrm{TW}_{5} \mathrm{~B}_{2.5}\right)$ increased soil $\mathrm{P}$ by $126 \%$, compared to the control. $\mathrm{TW}_{2.5} \mathrm{~B}_{2.5}, \mathrm{TW}_{5} \mathrm{~B}_{0}, \mathrm{TW}_{2.5} \mathrm{~B}_{0}$ and $\mathrm{TW}_{0} \mathrm{~B}_{2.5}$ increased soil $\mathrm{P}$ by $112,102,85$, and $60 \%$ respectively, compared to the control.

The effect of tannery wastes and biochar and their interaction effect on soil available potassium were not significant $(\mathrm{p}<0.05)$.

Soil EC increased with the increasing levels of tannery wastes (Table 2). The EC of tannery wastes was $17.01 \mathrm{dS}$ $\mathrm{m}^{-1}$, and $\mathrm{TW}_{2.5}$ and $\mathrm{TW}_{5}$ treatments increased soil EC significantly $(p<0.05)$ by 29 and $9 \%$, respectively, compared to the control. Reddi and Narasimha (2012) reported an increase in soil EC as a result of addition of tannery wastes due to accumulation of amino acids, acids, and alkaline materials in tannery wastes. The soil EC was increased by $10.8 \%$ in the biochar treatment (Table 2 ). Since electrical conductivity of biochar in this research was $4.2 \mathrm{dS} \mathrm{m} \mathrm{m}^{-1}$ (Table 1), a soil EC increase was expected. Amonette and Joseph (2009) reported that biochar ash usually contains a lot of calcium, magnesium, sodium, potassium, selenium, aluminium, and many other elements, therefore application thereof in high amounts may result in soil salinity stress. The interaction effect of tannery wastes with biochar on electrical conductivity (Fig. 1c) showed that at both biochar levels, application of tannery wastes increased soil EC significantly $(p<0.05)$. The highest EC was obtained in $\mathrm{TW}_{5} \mathrm{~B}_{2.5}$, which significantly differed compared to the other treatments $(\mathrm{p}<0.05)$. Similarly, biochar application at all levels of tannery wastes increased soil EC significantly $(\mathrm{p}<0.05)$.

The results of soil $\mathrm{pH}$ showed that only the treatment with tannery wastes increased soil $\mathrm{pH}$ significantly $(\mathrm{p}<0.05)$ and the highest $\mathrm{pH}$ was noted at the $\mathrm{TW}_{5}$ level (Table 2). Soil $\mathrm{pH}$ in the biochar treatment was not significant. Lentz and Ippolito (2012) reported on changes in soil $\mathrm{pH}$ as a result of biochar addition to calcareous soil. It seems that the high buffering capacity of alkaline soils is one of the important factors in buffering soil against $\mathrm{pH}$ changes (Afyuni, 1986). 


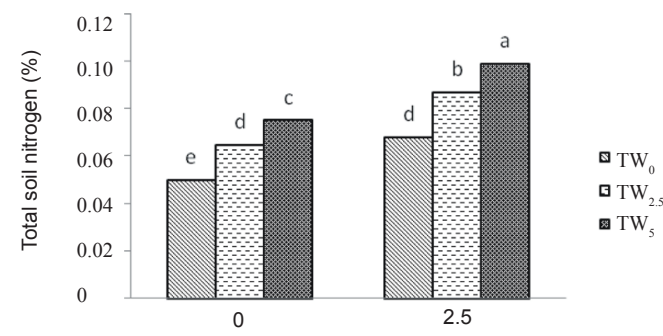

c

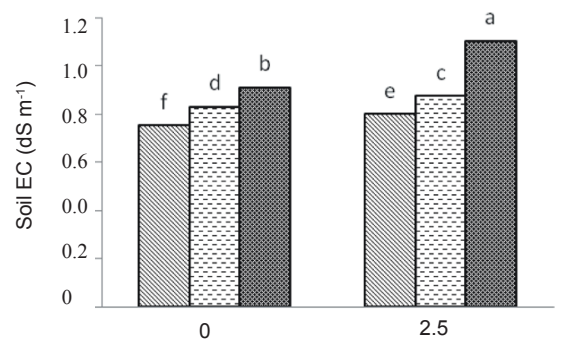

e

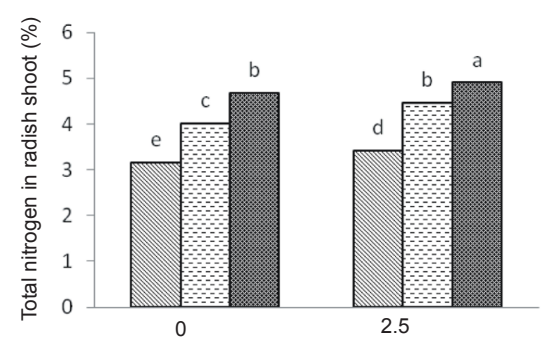

g

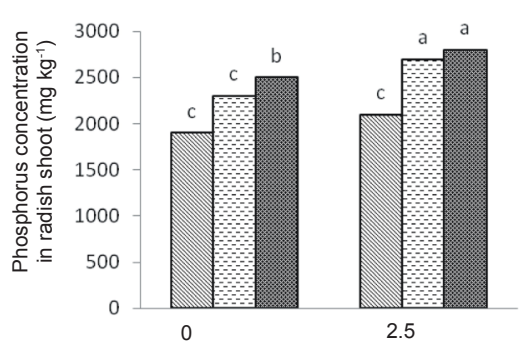

i

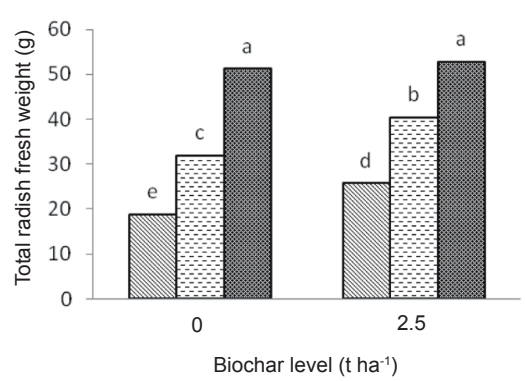

b

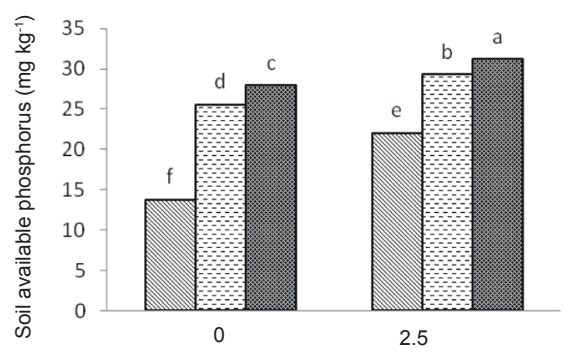

d

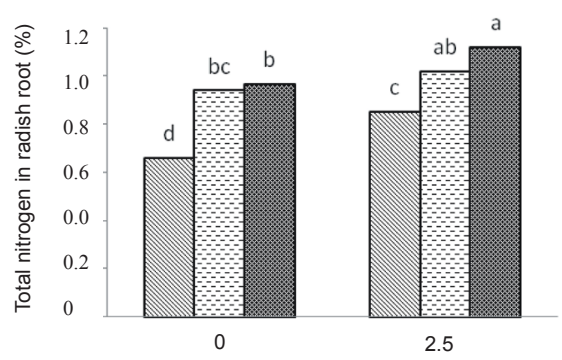

f

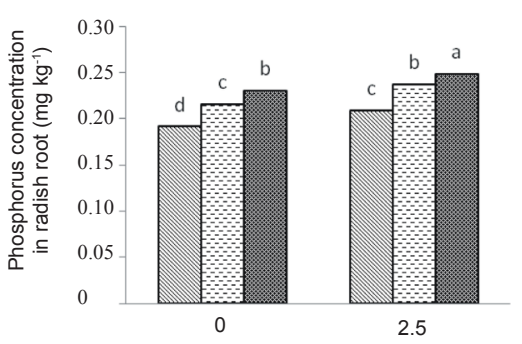

$\mathrm{h}$
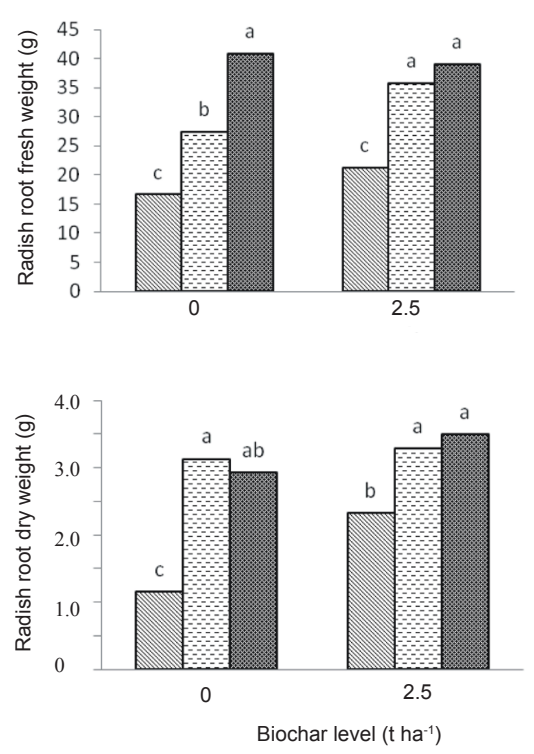

Fig. 1. Interaction effect of tannery wastes with biochar on: $a-$ soil total nitrogen, $b-$ soil available phosphorus, $c-$ soil EC, $d$ - total nitrogen of radish root, $\mathrm{e}$ - total nitrogen of radish shoot, $\mathrm{f}$ - phosphorus concentration of radish root, $\mathrm{g}$ - phosphorus concentration of radish shoot, $\mathrm{h}$ - fresh weight of radish root (g), i - total plant fresh weight, $\mathrm{j}$ - root dry weight, $\mathrm{k}$ - radish total dry weight, $\mathrm{l}$ - root diameter of radish. 


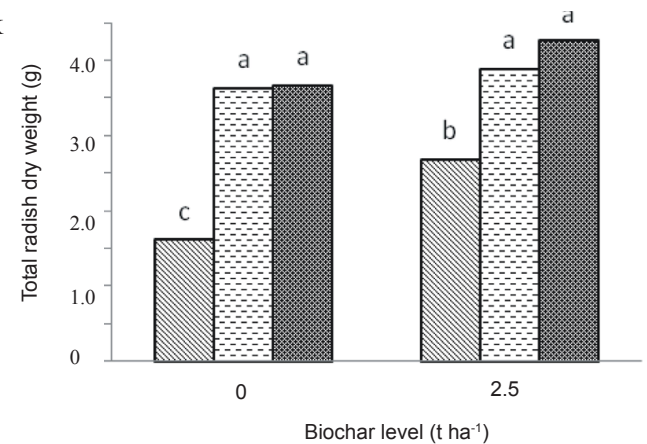

1

$\mathbb{\mathrm { TW } _ { 0 }}$

口 $\mathrm{TW}_{2.5}$

图W

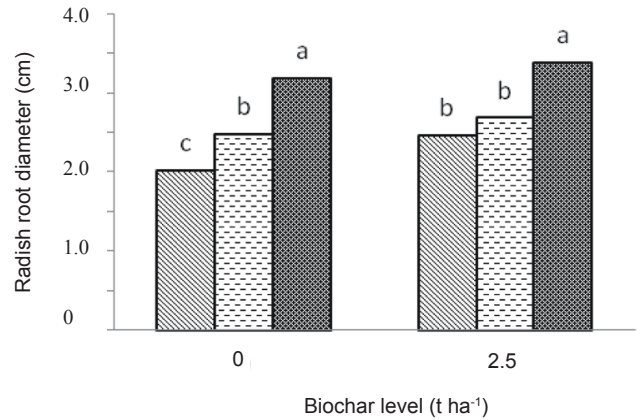

Fig. 1. Continuation.

T a b l e 3. Effect of tannery wastes and biochar on $\mathrm{N}, \mathrm{P}$, and $\mathrm{K}$ concentrations in radish

\begin{tabular}{lcccccc}
\hline \multirow{2}{*}{ Treatment } & $\mathrm{N}_{\text {shoot }}$ & $\mathrm{P}_{\text {shoot }}$ & $\mathrm{K}_{\text {shoot }}$ & $\mathrm{N}_{\text {root }}$ & $\mathrm{P}_{\text {root }}$ & $\mathrm{K}_{\text {root }}$ \\
\cline { 3 - 7 } & $(\%)$ & & & $\left(\mathrm{mg} \mathrm{kg}^{-1}\right)$ & & \\
\hline $\mathrm{TW}_{0}$ & $3.34 \mathrm{c}$ & $2000 \mathrm{c}$ & $6510 \mathrm{~b}$ & $0.762 \mathrm{~b}$ & $2000 \mathrm{c}$ & $20200 \mathrm{~b}$ \\
$\mathrm{TW}_{2.5}$ & $4.23 \mathrm{~b}$ & $2600 \mathrm{~b}$ & $6490 \mathrm{~b}$ & $0.994 \mathrm{a}$ & $2260 \mathrm{~b}$ & $20900 \mathrm{~b}$ \\
$\mathrm{TW}_{5}$ & $4.79 \mathrm{a}$ & $2700 \mathrm{a}$ & $7940 \mathrm{a}$ & $1.04 \mathrm{a}$ & $2390 \mathrm{a}$ & $21900 \mathrm{a}$ \\
$\mathrm{B}_{0}$ & $3.98 \mathrm{~b}$ & $2300 \mathrm{~b}$ & $7040 \mathrm{a}$ & $0.866 \mathrm{~b}$ & $2120 \mathrm{~b}$ & $21100 \mathrm{a}$ \\
$\mathrm{B}_{2.5}$ & $4.31 \mathrm{a}$ & $2500 \mathrm{a}$ & $6920 \mathrm{a}$ & $1.002 \mathrm{a}$ & $2310 \mathrm{a}$ & $20900 \mathrm{a}$ \\
\hline
\end{tabular}

Explanations as in Table 1.

Similarly, our finding in the studied alkaline soil showed a minor increase (by only $0.03-0.07$ ) in $\mathrm{pH}$ caused by the biochar and tannery waste addition.

The results obtained showed that application of both tannery wastes and biochar to soil significantly $(\mathrm{p}<0.05)$ increased the nitrogen concentration in radish shoots and roots, compared to the control (Table 3). The $\mathrm{TW}_{2.5}$ and $\mathrm{TW}_{5}$ treatments increased the nitrogen concentration in radish roots by 30 and $36 \%$ respectively, compared to the control. The shoot nitrogen concentration in the $\mathrm{TW}_{2.5}$ and $\mathrm{TW}_{5}$ treatments increased by 26 and $43 \%$, respectively compared to the control. Due to the high organic carbon and high nitrogen contents, tannery wastes are a good source of plant nitrogen (Nogueira et al., 2009). Collagen in tannery wastes is considered as a suitable resource for plant nitrogen availability (Lima et al., 2010). They reported that use of tannery wastes provided enough nitrogen for bean plants. Biochar addition increased the $\mathrm{N}$ concentration in radish roots and shoots by 15.7 and $8 \%$, respectively, compared to the control. Nigussie et al. (2012) reported that the use of 5 and $10 \mathrm{tha}^{-1}$ biochar increased the nitrogen concentration in lettuce. The interaction effect of tannery wastes and biochar on the $\mathrm{N}$ concentration in radish roots and shoots (Fig. 1d, e) showed that the $\mathrm{TW}_{5} \mathrm{~B}_{2.5}$ treatment increased the $\mathrm{N}$ concentration by $69 \%$ in roots and $55 \%$ in shoots compared to the control. The $\mathrm{TW}_{2.5} \mathrm{~B}_{2.5}$ treatment increased the $\mathrm{N}$ concentration by 54 and $41 \%$ in radish roots and shoots, respectively, compared to the control. At both biochar levels, addition of tannery wastes significantly increased the nitrogen concentration in roots and shoots, but the increase in the nitrogen concentration was not significant at both levels of tannery wastes $(\mathrm{p}<0.05)$. Biochar application at both levels of tannery wastes significantly increased the nitrogen in shoots shoot (except $\mathrm{TW}_{2.5}$ ), with an increasing amount of biochar. The $\mathrm{N}$ concentration in roots increased in $\mathrm{TW}_{0}$ and $\mathrm{TW}_{5}$. The intraction effect of tannery wastes and biochar on plant $\mathrm{N}$ was not significant.

The use of tannery wastes and biochar significantly $(p<0.05)$ increased the phosphorus concentration in both radish roots and shoots. $\mathrm{TW}_{2.5}$ and $\mathrm{TW}_{5}$ increased the phosphorus concentration in radish roots by 13 and $19 \%$, respectively, and in radish shoots by 30 and $35 \%$ compared to the control. Giachetti and Sebastiani (2007) found that the use of tannery wastes increased phosphorus in willow (Salix alba) especially in shoots. Phosphorus present in collagen of tannery wastes can be a suitable alternative for a phosphorus fertilizer, which showed satisfying results in rice (Oryza sativa L.). Some researchers emphasize that organic materials can increase plant available phosphorus and indirectly prevent phosphorus fixation in $\mathrm{pH} 6$ to 9 and increase available P (Baure and Black, 1992). Biochar treatment significantly $(\mathrm{p}<0.05)$ increased the $P$ concentration in radish roots and shoots by 8.9 and $8.7 \%$, respectively, compared to the control (Table 3). Zheng et al. (2010) reported 
T a b l e 4. Effect of tannery wastes and biochar on radish growth properties

\begin{tabular}{lcccccc}
\hline \multirow{2}{*}{ Treatment } & $\begin{array}{c}\text { Root fresh } \\
\text { weight }\end{array}$ & $\begin{array}{c}\text { Total plant fresh } \\
\text { weight }\end{array}$ & Root dry weight & $\begin{array}{c}\text { Total plant dry } \\
\text { weight }\end{array}$ & Root length & Root diameter \\
\cline { 2 - 6 } & \multicolumn{2}{c}{$(\mathrm{g})$} & & & $(\mathrm{cm})$ \\
\hline $\mathrm{TW}_{0}$ & $18.90 \mathrm{c}$ & $22.21 \mathrm{c}$ & $1.74 \mathrm{~b}$ & $2.14 \mathrm{~b}$ & $2.85 \mathrm{c}$ & $2.24 \mathrm{c}$ \\
$\mathrm{TW}_{2.5}$ & $31.62 \mathrm{~b}$ & $36.15 \mathrm{~b}$ & $3.20 \mathrm{a}$ & $3.76 \mathrm{a}$ & $3.21 \mathrm{~b}$ & $2.57 \mathrm{~b}$ \\
$\mathrm{TW}_{5}$ & $39.96 \mathrm{a}$ & $51.96 \mathrm{a}$ & $3.29 \mathrm{a}$ & $3.96 \mathrm{a}$ & $3.75 \mathrm{a}$ & $3.20 \mathrm{a}$ \\
$\mathrm{B}_{0}$ & $28.31 \mathrm{~b}$ & $33.94 \mathrm{~b}$ & $2.40 \mathrm{~b}$ & $2.97 \mathrm{~b}$ & $3.26 \mathrm{a}$ & $2.55 \mathrm{~b}$ \\
$\mathrm{~B}_{2.5}$ & $32.01 \mathrm{a}$ & $39.61 \mathrm{a}$ & $3.03 \mathrm{a}$ & $3.61 \mathrm{a}$ & $3.28 \mathrm{a}$ & $2.84 \mathrm{a}$ \\
\hline
\end{tabular}

Explanations as in Table 1.

increasing phosphorus in corn as a result of biochar application. The interaction effect of tannery wastes and biochar on the $\mathrm{P}$ concentration in radish roots and shoots (Fig. 1f, g) showed that the $\mathrm{TW}_{5} \mathrm{~B}_{2.5}$ treatment increased the phosphorus concentration in radish roots and shoots by 30 and $47 \%$, respectively, compared to the control. Biochar application at both levels of tannery wastes significantly increased phosphorus in roots and shoots compared to the control.

The application of tannery wastes increased the potassium concentration in both roots and shoots significantly $(\mathrm{p}<0.05)$ except for $\mathrm{TW}_{2.5}$ for roots and shoots, where the $\mathrm{K}$ concentration was lower than that in the control. The $\mathrm{K}$ concentration in the roots was much higher than in the shoots (Table 3). Giachetti and Sebastiani (2007) reported an increasing potassium concentration in willow (Salix $a l b a$ ) due to application of 150 and $300 \%$ of tannery wastes. Francisco et al. (2011) found that the potassium concentration increased in rice (Oryza sativa L.) as a result of biochar application. Sommers (1977) concluded that the potassium concentration in tannery wastes was 0.02 to $2.6 \%$, which is enough for plant uptake. The biochar treatments showed no significant effect on the potassium concentration in radish roots and shoots.

The results of both 2.5 and $5 \%$ levels of tannery wastes significantly $(p<0.05)$ increased fresh root and total weight of radish (Table 4) compared to the control. Root and total dry weight of radish in $\mathrm{TW}_{2.5}$ and $\mathrm{TW}_{5}$ increased significantly $(p<0.05)$ compared to the control (Table 4). Asfaw et al. (2012) reported that growth and germination of Swiss chard, beet root, and cabbage root increased due to application of $25,50,75$, and $100 \%$ tannery wastes to soil. Both levels of tannery wastes increased root height and diameter significantly $(\mathrm{p}<0.05)$ compared to the control (Table 4$)$. Biochar as well as tannery wastes increased both root and total fresh and dry weight and the root diameter of radish. Several greenhouse and field studies have been conducted to examine the effect of biochar on crop yield (Chan et al.,
2007). Most studies showed that addition of biochar to soil increased crop yields. Chan et al. (2007) reported increasing crop yield and soil quality improvement as a result of addition of green waste-derived biochar to soil. The interaction effect of tannery wastes and biochar on fresh and dry weight and root diameter of radish showed that (Fig. 1 h, i, j, k, l) application of biochar along with tannery wastes increased plant yield significantly. Tannery wastes of $5 \%$ had a significant effect on fresh weight compared to the $2.5 \%$ level, and increased more compared to the control $(p<0.05)$.

\section{CONCLUSIONS}

1. The results showed that tannery wastes at both 2.5 and 5\% levels increased the soil nitrogen and phosphorus concentration, but did not produce any significant increase in the $\mathrm{K}$ soil concentration. In turn, the biochar treatment decreased electrical conductivity of soil.

2. Soil nitrogen and phosphorus concentrations in both biochar and tannery waste treatments were similar. The interaction effect of tannery wastes and biochar on soil showed that the nitrogen and phosphorus concentrations increased as a result of combined application thereof.

3. Tannery wastes increased the nitrogen and phosphorus concentrations in both radish roots and shoots, and the $5 \%$ tannery waste treatment yielded the highest increase, compared to the control. The interaction effect of tannery wastes and biochar on plant showed that tannery wastes at both levels along with biochar yielded a more considerable increase in the growth of radish roots and shoots.

4. The results of application of tannery wastes on plant yield showed that at both levels of tannery wastes, fresh (63 and $134 \%$ ) and dry weight (76 and $85 \%$ ), and root height (13 and 32\%), and diameter of radish (15 and 43\%) were increased compared to the control. 
5. Given their high nutrient content, application of biochar and tannery wastes is recommended in soils with low organic carbon and in calcareous soil, especially at the 5\% level in order to increase plant growth and yield.

\section{REFERENCES}

Afyuni M., 1986. Extractability of $\mathrm{Fe}, \mathrm{Zn}$, and $\mathrm{Cd}$ in sludge amended calcareous soils. MSc. Thesis, New Mexico State Univ., Las Cruces, NM, USA.

Amonette J. and Joseph S., 2009. Characteristics of biochar micro - chemical properties. In: Biochar for Environmental Management - Science and technology (Eds J. Lehman, S. Joseph), Earthscan, London, UK.

Asfaw A., Sime M., and Itanna F., 2012. Determining the effect of tannery effluent on seeds germination of some vegetables in Ejersa Area of east Shoa, Ethiupia. Int. J. Scient. Res., 2(12), 2250-3153.

Basegio T., Beck A., Bernardes A., and Bergmann C., 2009. An alternative to minimize environmental impact caused by leather industry wastes. J. Hazard. Mat., 165, 604-611.

Baure A. and Black A.L., 1992. Organic carbon effects on available water. Soil Sci. Soc. Am. J., 56, 248-254.

Chan K.Y., Zwieten L.V., Meszaros I., Downie A., and Joseph S., 2007. Agronomic values of greenwaste biochar as a soil amendment. Aust. J. Soil Res., 45, 629-634.

Dudka S. and Miller W.P., 1999. Accumulation of potentially toxic elements in plants and their transfer to human food chain. J. Environ. Sci. Heal., 34, 681-708.

Francisco G.E., Isabela A., Castroa R.R., Guilherme A., Janice G., and Luiz C.A., 2011. Recycling of solid waste rich in organic nitrogen from leather industry: Mineral nutrition of rice plants. J. Hazard. Mat., 186, 1064-1069.

Giachetti G. and Sebastiani L., 2007. Effects of tannery waste on growth dynamics and metal uptake in Salix alba L. Plant Biosys., 141, 22-30.

Kimetu J.M., Lehmann J., Ngoze S.O., Mugendi D.N., Kinyangi J.M., Riha S., Verchot L., Recha J.W., and Pell A.N., 2008. Reversibility of soil productivity decline with organic matter of differing quality along a degradation gradient. Ecosys., 11, 726-739.

Konrad E.E. and Castilhos D.D., 2002. Soil chemical changes and corn growth as affected by the addition of tannery sludges. R. Bras. Ci. Solo., 26, 257-265.

Laird D.A., 2008. The charcoal vision: A win-win-win scenario for simultaneously producing bioenergy, permanently sequestering carbon, while improving soil and water quality. Agron. J., 100, 178-181.

Laird D., 2009. Impact of Biochar Amendments on Soil Quality for a Typical Midwestern Agricultural Soil. University of Colorado, Boulder, CO, USA.
Lentz R.D. and Ippolito J.A., 2012. Biochar and manure affect calcareous soil and corn silage nutrientconcentrations and uptake. Environ. Qual., 41, 1033-1043.

Lima D.Q., Oliveira L.C.A., Bastos A.R.R., Carvalho G.S., Marques J.G.S.M., Carvalho J.G., and Souza G.A., 2010. Leather industry solid waste as nitrogen source for growth of common bean plants. Appl. Environ. Soil Sci., 2010, 1-7.

Major J., 2009. Biochar application to a Colombia savanna Oxisol: fate and effect on soil fertility, crop production, nutrient leching and soil hydrology. Department of Crop and Soil Siences, Cornell University, New York, NY, USA.

Meehan B., Maheswaran J., and Phung K., 2001. Re-use potential of agriculture industry wastes. A Report for the Rural Industries Research and Development Corporation. Melbourne, Australia.

Nigussie A., Kissi E., Misganaw M., and Ambaw G., 2012. Effect of biochar application on soil properties and nutrient uptake of lettuces (Lactuca sativa) Grown in Chromium Polluted Soils. Am. Euros. J. Agri. Environ. Sci., 12(3), 369-376.

Nogueira F.G.E., Prado N.T., Oliveira L.C.A., Bastos A.R.R., Lopes J.H., and Carvalho J.G., 2009. Incorporation of mineral phosphorus and potassium on leather waste (collagen). J. Hazard. Mat., 176, 374-380.

Oliveira D.Q.L., Carvalho K.T.G., Basto A.R.R., Oliveira L.C.A., Marques J.J.G.M.M., and Nascimento R.S.M.P., 2008. Use of industry of leather residues as nitrogen source for the elephantgrass. Rev. Biasil. de Cien. do Sol, 32, 417-424.

Page A.L., Miller R.H., and Keeney D.R., 1982. Methods of Soil Analysis, part 2, chemical and microbiological properties. ASA and SSSA, Madison, WI, USA.

Reddi M. and Narasimha G., 2012. Effect of leather industry effluents on soil microbial and protease activity. J. Environ. Biol., 33, 39-42.

Richards L.A., 1954. Diagnosis and improvement of saline and alkali soil. USDA. Agriculture, Hand Book, No. 60.

Sommers L.E., 1977. Chemical composition of sewage sludge and analysis of their potential use as fertilizers. J. Environ. Qual., 6, 220-225.

Yao Y., Gao B., Zhang M., Inyang M., and Zimmerman A.R., 2012. Effect of biochar amendment on sorption and leaching of nitrate, ammonium, and phosphate in a sandy soil. Chemosp., 89, 1467-1471.

Yu X.Y., Ying G.G., and Kookana R.S., 2009. Reduced plant uptake of pesticides with biochar additions to soil. Chemosp., 76, 665-671.

Zheng W., Sharma B.K., and Rajagopalan N., 2010. Using Biochar as a Soil Amendment for Sustainable Agriculture. Illinois Sustainable Technology Center, Illinois, USA. 